\title{
Influence of stromal-epithelial interactions on androgen action
}

\author{
Cera M Nieto, Leah C Rider and Scott D Cramer \\ Department of Pharmacology, University of Colorado Anschutz Medical Campus, Aurora, Colorado, USA
}

Correspondence should be addressed to S D Cramer

Email

Scott.Cramer@ucdenver.edu

\begin{abstract}
Androgen receptor (AR) signaling is vital to the development and function of the prostate and is a key pathway in prostate cancer. AR is differentially expressed in the stroma and epithelium, with both paracrine and autocrine control throughout the prostate. Stromalepithelial interactions within the prostate are commonly dependent on AR signaling and expression. Alterations in these pathways can promote tumorigenesis. AR is also expressed in normal and malignant mammary tissues. Emerging data indicate a role for AR in certain subtypes of breast cancer that has the potential to be exploited therapeutically. The aim of this review is to highlight the importance of these interactions in normal development and tumorigenesis, with a focus on the prostate and breast.
\end{abstract}

\author{
Key Words \\ - androgens \\ - androgen receptor \\ - breast \\ - prostate
}

Endocrine-Related Cancer (2014) 21, T147-T160

\section{Introduction}

The role of androgens in the maintenance of prostate structure, development, and growth and in the stimulation of prostate cancer cells has been studied since the pioneering work of Huggins in the 1940s (Huggins et al. 1939, Huggins \& Clark 1940, Huggins \& Sommer 1953). The androgen receptor (AR) is a central mediator of androgen action in all tissues that are androgenresponsive. The role of AR can be paradoxical, with both stimulatory and anti-proliferative actions, depending on the microenvironment and hormone levels. Reciprocal $\mathrm{AR}$ responses in the epithelium and stroma are involved in tissue development and homeostasis and aberrant responses can lead to the disruption of these processes, resulting in tumorigenesis. Understanding these processes could lead to strategies designed to halt or prevent the development of malignant disease. AR is also expressed in normal mammary tissue and has a demonstrated hormonal role in breast development. AR may regulate tumorigenic properties and contribute to epithelialmesenchymal signaling in the breast, though the information is limited. There are many other wellcharacterized AR target tissues throughout the body, but specific information on the role of AR in epithelialmesenchymal interactions is minimal or non-existent (Chang et al. 2013). This review focuses on the role of AR in the prostate and, to a lesser extent, in the breast, specifically in the context of interactions between the epithelium and the stroma.

\section{Androgens in development}

\section{Prostatic development}

The human prostate develops from the urogenital sinus (UGS). $5 \alpha$-Reductase is present in the fetal UGS and is the main enzyme involved in the conversion of testosterone into the more potent dihydrotestosterone (DHT; Shimazaki et al. 1965). In Fig. 1, this mechanism is shown in relation to the AR. Androgens produced by Leydig cells in males stimulate the UGS to undergo epithelial bud 

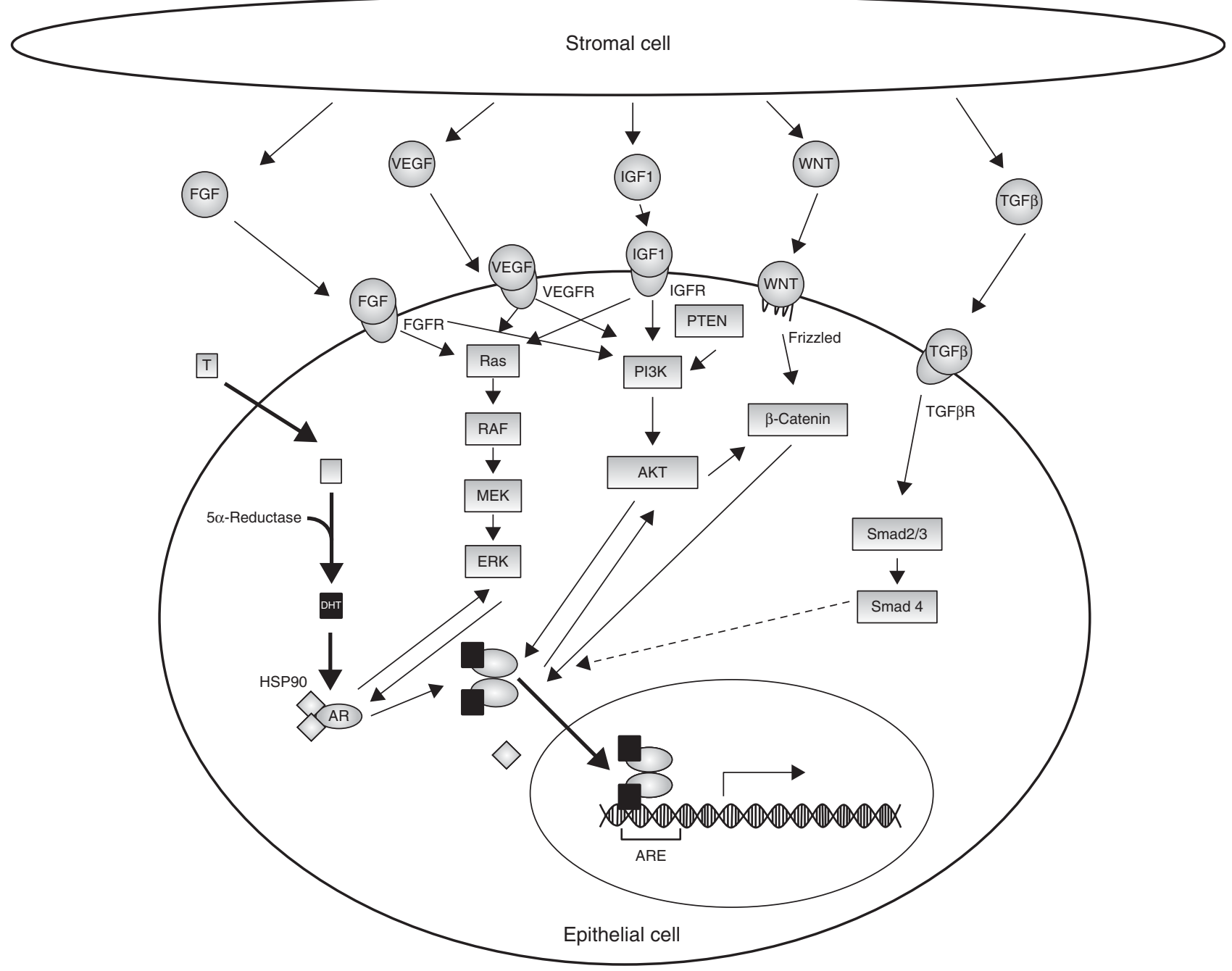

Figure 1

Overview of AR-regulated stromal-epithelial signaling pathways in prostate cancer. DHT, dihydrotestosterone; HSP90, heat-shock protein 90 ; $A R$, androgen receptor; ARE, androgen response element; FGF, fibroblast growth factor; VEGF, vascular endothelial growth factor; IGF1, insulin-like

formation and branching. This process occurs during weeks 8-10 in human gestation and E13.5-E15.5 in murine gestation (Meeks \& Schaeffer 2011). The expression of $\mathrm{AR}$ in the developing prostate indicates that there is a functional role for androgens prior to maturation. The development of the $A r$-knockout (ARKO) mouse has significantly strengthened our understanding of the tissue-specific functions of AR in vivo (Matsumoto et al. 2003, Yeh et al. 2003, De Gendt et al. 2004, Holdcraft \& Braun 2004, Notini et al. 2005). The double-stroma and smooth-muscle ARKO (dARKO) mouse exhibits decreased prostatic bud formation and branching patterns (Lai et al. 2012). Evidence of this is also described in the context of growth factor 1; TGF $\beta$, transforming growth factor beta; PTEN, phosphatase and tensin homolog; PI3K, phosphatidylinositol-4,5-biphosphate 3-kinase; AKT, protein kinase B.

the external genitalia (Weiss et al. 2012). Further differentiation of the prostate occurs post-natally. Fetal prostatic epithelium and surrounding stroma exhibit similar levels of AR mRNA and protein expression, but the epithelial AR lacks ligand-binding ability until post-parturition (Takeda $\&$ Chang 1991). Complete differentiation of the prostate is delayed until puberty, when a surge in androgen levels stimulates differentiation (Van Wagenen 1947).

Cunha et al. have rigorously shown that AR-positive urogenital mesenchyme (UGM) is the driving force behind the differentiation of the AR-negative fetal urogenital epithelium through tissue recombination experiments. In tissue recombination, fetal rat UGM is recombined with

Published by Bioscientifica Ltd 
epithelial cells and implanted under the murine renal capsule. The graft is allowed to grow for $\geq 8$ weeks. The result is a graft of fully differentiated prostatic tissue. The UGM is the driving inductive force behind prostatic differentiation; provided the epithelium is of endodermal origin (i.e. prostate, bladder, and salivary gland), its source is not as critical. Importantly, neither UGM nor epithelium alone can produce a graft with a prostatic phenotype; androgens and stromal-epithelial interactions are required for proliferation and differentiation (Cunha 1972, 1984, Cunha \& Chung 1981, Cunha et al. 1983, 1987).

Donjacour \& Cunha elaborated on the temporal relationship between differentiation and AR with testicular feminized mice $\left(\mathrm{X}^{\mathrm{Tfm}}\right)$ mice, which have a defect in the Ar locus. When prostatic, bladder, or urethral epithelium was recombined with normal UGM, fully differentiated prostatic structures developed, complete with mouse dorsolateral secretory protein (mDLP) staining. The prostate, bladder, and urethra are endodermal tissues, so UGM drives prostatic differentiation, and germline differences are not important (Donjacour \& Cunha 1995). When $X^{\mathrm{Tfm}}$ UGM is recombined with WT bladder/urethral epithelium, a vaginal-like phenotype is observed, indicating that the expression of AR exclusively in the epithelium is not enough to drive prostatic differentiation. Embryonic AR in the UGM is required to form a prostate-like graft. When WT UGM was recombined with $\mathrm{X}^{\mathrm{Tfm}}$ bladder/urethral epithelium, a well-organized prostatic graft developed (Cunha \& Lung 1978, Cunha \& Chung 1981, Shannon \& Cunha 1984, Sugimura et al. 1986). However, when histologically analyzed, mDLP staining was negative. This demonstrates that the complete exocrine differentiation of luminal cells is dependent on post-embryonic AR in the epithelium (Donjacour \& Cunha 1993). UGM recombined with epithelium from $\mathrm{X}^{\mathrm{Tfm}}$ mice does not produce a graft when implanted in a male host. A summary of these experiments is given Table 1.

Prostatic development in the prostate epithelia-specific ARKO (pes-ARKO) mouse also showed an important role for the epithelial AR. Niu et al. (2008) determined that pesARKO mice exhibit increased apoptosis of luminal cells and increased proliferation of basal cells. Reciprocally, maintenance of the prostatic epithelium is dependent on the stromal AR. Cunha et al. used tissue recombination experiments to show that loss of $A r$ in the stroma affects the apoptotic index of the epithelium. The authors suggest that the stromal AR, rather than the epithelial AR, is the primary determinant of the hormone-dependent apoptotic index (Kurita et al. 2001). In the context of the dARKO mouse, loss of $A r$ in the stroma results in a decrease in epithelial cell proliferation and an increase in apoptosis. This effect is thought to occur due to a lack of stromal factors such as collagen matrix, altered gene expression, and reduction of growth factors (Lai et al. 2012, Yu et al. 2012). Altogether, this demonstrates the powerful cues of both the epithelium and the stroma, as well as the role of AR. A summary of ARKO mouse models used to study the role of AR in the prostate is given in Table 2 .

\section{Breast development}

During embryonic development, both male and female mice initially develop a mammary bud at day 12 of gestation, but the mammary bud of male mice regresses during late gestation. The mammary bud becomes androgen-responsive from day 14 to parturition (Wasner et al. 1983). Further investigation has shown that the mammary epithelium signals the surrounding mesenchyme to express AR. The AR-positive mesenchyme encloses the mammary epithelium and induces involution

Table 1 Summary of the recombinant experiments reviewed

\begin{tabular}{|c|c|}
\hline Tissue recombinants & Graft phenotype \\
\hline WT UE + WT UGM & $\begin{array}{l}\text { Prostatic } \\
\text { AR-negative basal layer } \\
\text { AR-positive luminal layer } \\
\text { mDLP-positive }\end{array}$ \\
\hline Tfm UE + WT UGM & $\begin{array}{l}\text { Prostatic } \\
\text { AR-negative basal layer } \\
\text { AR-negative luminal layer } \\
\text { mDLP-negative }\end{array}$ \\
\hline WT UE + Tfm UGM & Vaginal \\
\hline Tfm UE + Tfm UGM & $\begin{array}{l}\text { Undifferentiated growth in male host } \\
\text { Vaginal in female host }\end{array}$ \\
\hline
\end{tabular}

References
Cunha \& Lung (1978), Shannon \& Cunha
(1984) and Donjacour \& Cunha (1993)
Cunha \& Lung (1978), Shannon \& Cunha
(1984) and Donjacour \& Cunha (1993)
Cunha \& Lung (1978)
Cunha \& Lung (1978)

UE, urothelium; UGM, urogenital mesenchyme; Tfm, testicular feminized; AR, androgen receptor; mDLP, mouse dorsolateral secretory product $B$.

http://erc.endocrinology-journals.org DOI: 10.1530/ERC-14-0138
(C) 2014 Society for Endocrinology Printed in Great Britain
Published by Bioscientifica Ltd 
Table 2 Mouse models used to study the role of AR expression in the prostate

\begin{tabular}{|c|c|}
\hline ARKO model & Prostatic phenotype \\
\hline FSP-ARKO & $\begin{array}{l}\uparrow \text { Apoptosis } \\
\downarrow \text { Epithelial proliferation } \\
\downarrow \text { Collagen matrix }\end{array}$ \\
\hline dARKO & $\begin{array}{l}\uparrow \text { Epithelial apoptosis } \\
\downarrow \text { Anterior lobe size } \\
\downarrow \text { Branching morphogenesis } \\
\downarrow \text { Epithelial proliferation }\end{array}$ \\
\hline pes-ARKO & $\begin{array}{l}\uparrow \text { Luminal proliferation } \\
\uparrow \text { CK5+/CK8+intermediate progenitor } \\
\downarrow \text { Epithelial proliferation } \\
\downarrow \text { Differentiation } \\
\text { Hyperproliferative }\end{array}$ \\
\hline Total ARKO & $\begin{array}{l}\text { No prostate formation } \\
\text { Undifferentiation }\end{array}$ \\
\hline
\end{tabular}

\author{
References \\ Yu et al. (2012) \\ Lai et al. (2012) \\ Wu et al. (2006), Niu et al. $(2008,2011)$ and \\ Lee et al. (2012) \\ Matsumoto et al. (2003), Yeh et al. (2003), \\ De Gendt et al. (2004), Holdcraft \& \\ Braun (2004) and Notini et al. (2005)
}

ARKO, androgen receptor knockout, FSP-ARKO, prostatic stromal fibroblast ARKO; dARKO, double-stroma and smooth-muscle ARKO; pes-ARKO, prostate epithelia-specific ARKO.

of the mammary bud. Androgens directly act on the surrounding stroma to control subsequent epithelial changes (Kratochwil 1969, Kratochwil \& Schwartz 1976, Durnberger \& Kratochwil 1980, Heuberger et al. 1982, Wasner et al. 1983). The induction of mesenchymal AR expression by the adjacent mammary epithelium appears to be mammary epithelium-specific. When mammary mesenchyme was recombined with epithelium from epidermis or pancreas, no expression of AR was observed in the mammary mesenchyme. Salivary epithelium was found to elicit a mild response (Heuberger et al. 1982). Female murine and human mammary tissues express AR (Boutin \& Cunha 1997), and androgens play a role in counteracting the proliferative effects of estrogens. This is especially important during puberty when the AR level in the mammary fat pad doubles (Peters et al. 2011). In Ar-null female mice, mammary gland development and branching are inhibited (Yeh et al. 2003). Overall, the available data indicate that normal mammary tissue expresses AR, which plays an anti-proliferative role.

\section{Androgens post-puberty}

\section{The normal prostate}

The completely differentiated prostate is composed of an epithelial bilayer surrounded by stroma. The stroma consists of AR-positive smooth-muscle cells, fibroblasts, myofibroblasts, extracellular matrix (laminin and collagenrich), immune cells, innervation, and vasculature. The basal lamina surrounds the epithelium and forms a barrier between the epithelium and the stroma. The epithelial compartment is composed of an AR-negative basal cell layer with rare AR-negative neuroendocrine cells interspersed. The epithelial compartment also contains an AR-positive luminal cell layer, which produces prostatic secretory protein. Along with these fundamental prostatic epithelial cells, there are also prostatic stem cells, progenitor cells, and transit-amplifying cells (Barron \& Rowley 2012, Frank \& Miranti 2013). Though the AR-positive stroma produces strong inductive cues, these are not enough to form a completely differentiated prostate (see the discussion above). Furthermore, without a constant supply of androgens, the prostate gland will begin to regress, especially the AR-positive luminal cells (Hayward et al. 1996).

\section{The normal breast}

$\mathrm{AR}$ is found throughout human and murine mammary tissues, specifically in luminal, myoepithelial, and stromal cells within the acini. AR is also found in the adipose tissue (Hickey et al. 2012). The overall AR protein level in female mice is about one-third that in male mice. In normal mammary tissue, AR serves as a tumor suppressor, inhibiting the stimulatory effects of estrogen receptor alpha (ER $\alpha$; Peters et al. 2009). The levels of AR remain relatively consistent throughout a menstrual cycle, but drop during pregnancy and lactation. This is probably to allow for higher ER $\alpha$-regulated proliferation, but the mechanism is still unclear (Hickey et al. 2012).

Overall, studies in both mammary and prostatic tissues define an essential role of AR in the development and maintenance of normal glandular organization and integrity.

Published by Bioscientifica Ltd 


\section{Cancer}

\section{Inductive effects of stroma in prostate cancer}

The role of the tumor microenvironment in prostate tumorigenesis has gained increasing attention since the seminal experiments of Cunha \& Chung (1981) have demonstrated that prostate cancer-associated fibroblasts (CAFs) stimulate tumorigenesis in the benign prostatic hyperplasia (BPH)-1 cell line (Olumi et al. 1999). BPH1 is an SV40 T-antigen-transformed human prostatic cell line that originated from BPH cells. Olumi et al. (1999) were the first to show that prostate CAFs promote BPH1 tumorigenesis. When grafted alone, or with normal peripheral zone-associated fibroblasts (NPFs), BPH1 cells are not tumorigenic. However, when BPH1 cells are combined with CAFs and grafted under the renal capsules of nude mice, they form tumors. Signaling by transforming growth factor beta (TGF $\beta$ ) and stromal cell-derived factor 1 (SDF1) has been proposed as a mechanism by which CAFs can induce adjacent epithelial cells to proliferate (Ao et al. 2007). Subsequent studies carried out by several groups have confirmed these findings and extended them. BPH1 epithelial cells can also be stimulated to form aggressive, metastatic cancer cells via hormone stimulation alone. Wang et al. showed that when BPH1 cells were recombined with rat UGM, a well-organized, benign graft formed under the renal capsule. In the presence of testosterone or $17 \beta$-estradiol $\left(\mathrm{E}_{2}\right)$, BPH1 cells with UGM formed aggressive cancer cells that maintained this phenotype through several in vivo passages. Epithelial apoptosis occurred when these animals were castrated (Wang et al. 2001). The $5 \alpha$-reductase inhibitor finasteride decreases the expression of AR exclusively in the epithelium (Bauman et al. 2014). Similar findings associated with CAF induction and hormone-stimulated growth have also been reported (Hayward et al. 2001). In addition, Thalmann et al. (2010) have demonstrated the ability of CAFs to promote castration resistance in an LNCaP model, indicating that the CAFs contribute to lethal disease. We demonstrated that distinct populations of stromal cells reside in the prostate tumor microenvironment relative to stromal cells from normal prostate peripheral zone tissue and, more importantly, relative to stromal cells in $\mathrm{BPH}$ tissue (Barclay et al. 2005).

McNeal (1990) has suggested that BPH is a disease of the prostatic stroma. His observations have led to the hypothesis that BPH occurs as a result of the reawakening of the embryonic inductive abilities of the prostatic stroma. Recent work has also reported $\mathrm{BPH}$ to be associated with inflammation via activating protein 1 (Lin-Tsai et al. 2014). BPH tissue has significantly greater AR expression in both the epithelium and stroma compared with normal glandular tissue. Interestingly, the expression of ER $\alpha$ (ESR1) dramatically increases in the epithelium and is much lower than normal levels in the stroma (Nicholson et al. 2013). The estrogen antagonist raloxifene has been shown to inhibit BPH epithelial growth and may be a major mediator of epithelialto-mesenchymal transition (EMT) in BPH tissue (Yang et al. 2010, Shao et al. 2014). The inductive abilities of the $\mathrm{BPH}$ stroma are thought to be embryonic signals that induce normal epithelial structures. The overexpression of cyclin D1 in CAFs has been suggested as a possible mechanism for their inductive capabilities. Normal prostate fibroblasts exhibiting cyclin D1 overexpression have been shown to induce a malignant transformation of the BPH1 epithelial cell line in vivo (He et al. 2007). Cathepsin D is required for the contribution of cyclin D1 to NPF malignancy, and overexpression of cathepsin D in the stroma promotes tumor growth (Pruitt et al. 2013). This is only one of the many examples of genetic alterations promoting tumorigenesis in CAFs. Love et al. (2009) identified numerous AR-regulated genes in human $\mathrm{BPH}$ xenografts grown in mice. CAFs and prostate cancer epithelium are also able to reciprocally regulate metabolism. Fiaschi et al. (2012) have shown that CAFs are stimulated to favor Warburg metabolism after contact with prostate cancer epithelium and that prostate cancer cells favor aerobic metabolism after contact with CAFs.

The zone of the prostate is an important prognostic factor in prostate cancer. BPH commonly occurs in the transition zone, while prostate cancer is mostly found in the peripheral zone (McNeal et al. 1988, Grignon \& Sakr 1994, Brossner et al. 2003, Pavelic et al. 2003). These zones are markedly different. The transition zone has greater cell density and ER activity, while the peripheral zone has greater AR activity (Feneley et al. 1995). It was shown that, under elevated levels of DHT and $E_{2}, A R$ is more highly expressed in the peripheral zone than in the transition zone. Under these conditions, the peripheral zone also has a greater capacity to induce tumor growth via androgen-regulated growth factors such as TGF $\beta 1$ and insulin-like growth factor 1 (IGF1; Jiang et al. 2011). In Fig. 1, a schematic of androgen-regulated signaling pathways in prostate cancer is shown. CAFs from both the peripheral and transitional zones can induce a metastatic phenotype in the normally non-metastatic LNCaP cell line in vivo, but the mechanisms are unclear (Thalmann et al. 2010). Reactive stroma is also a major

Published by Bioscientifica Ltd. 
problem in prostate cancer progression. The stroma develops a 'wound that will not heal' phenotype (Dvorak 1986), with a constant immune response that leaves the microenvironment unstable. The role of $\mathrm{AR}$ in reactive stroma is still undefined (Barron \& Rowley 2012).

\section{Effects of stromal androgens}

The mRNA levels of $A R$ are very similar in the stroma and the epithelium, but transcription is differentially regulated in each. This allows for more active co-regulator recruitment by the epithelium. In prostate cancer, this co-regulator recruitment is altered within the microenvironment, especially within the androgen-responsive genes. Co-culture between stromal and epithelial cells was used to assess co-regulator recruitment to an exogenous MMTV-driven promoter in the stroma. CAFs were found to have impaired recruitment relative to NPFs. Some of the major co-regulators found in this system were SRC1, NCoR, and SMRT (Cano et al. 2007). AR may also regulate the stroma by inducing the differentiation of myofibroblasts via TGF $\beta$, altering the tumor microenvironment according to androgen action (Gerdes et al. 2004). These findings demonstrate that stromal-epithelial interactions influence AR signaling as well as tumorigenesis.

The previously described BPH1 cell line was recombined with UGM from $X^{\mathrm{Tfm}} / \mathrm{Y}$ mice, and it was shown that BPH1 cells did not develop tumors without the stromal AR. However, when human BPH1 cells were recombined with WT rat UGM, grafts formed consistently (Ricke et al. 2012). It is important to note that ER $\beta$ (ESR2), expressed exclusively in the epithelium, has also been reported to be involved in anti-proliferative effects in the prostate. These effects are dependent on functional aromatase in the stroma. Furthermore, conditioned media from the stroma have been shown to stimulate growth in human prostatic cell lines, possibly through the AR-mediated ERK pathway (Shigemura et al. 2009). Studies carried out in the dARKO mouse, in the context of heterozygous loss of phosphatase and tensin homolog (Pten), have demonstrated that loss of stromal Ar could inhibit prostatic intraepithelial neoplasia (PIN) (Lai et al. 2012). PTEN function is commonly lost in prostate cancer cells and is associated with increased cell proliferation via Akt and PI3K activities (Fig. 1; Simpson \& Parsons 2001). There is evidence that a transition from a paracrine to an autocrine mechanism of growth stimulated by the stroma occurs within the prostatic epithelial cells, which are also stimulated by androgens (Gao et al. 2001).

There is conflicting evidence concerning the AR status of the stroma. Ricke et al. (2012) showed that prostate cancer is dependent on stromal androgens and not on epithelial androgens. Previous studies have demonstrated that low stromal AR levels are indicative of a poor outcome after castration. This may be dependent on the high levels of $\mathrm{AR}$ in the epithelia, but further study is required (Henshall et al. 2001, Ricciardelli et al. 2005, Wikstrom et al. 2009). Recent work has shown that the AR in myofibroblasts may be an indicator of a better outcome. Hic5 collaborates with AR in the stroma to inhibit migration and invasion (Leach et al. 2014). In addition, there is evidence that typically androgen-independent growth factors such as fibroblast growth factor 7 (FGF7 or KGF) may be activated under androgen deprivation therapy (ADT) conditions (Ishii et al. 2009). Specific targeting of the stromal AR may yield different results. Yu et al. (2013) have suggested that the expression of AR in CAFs regulates epithelial proliferation via various growth factors such as IGF1, FGF7, FGF10, SDF1, HGF, and TGF $\beta 2$. This would indicate that preferential targeting of AR in the stroma might be a therapeutic option. The AR status of the stroma plays an important role in outcome, but primary cells tend to lose $A R$ expression in culture. For this reason, an AR-positive stromal cell line was developed via lentiviral overexpression in the WPMY cell line (Tanner et al. 2011). It is unclear exactly what role the stromal AR plays in cancer progression, but co-targeting both the stroma and the epithelium may be a promising therapeutic strategy (Hsieh et al. 2004, Niu et al. 2008).

\section{Castration-resistant prostate cancer}

Castration-resistant prostate cancer (CRPC) is an aggressive, late stage of prostate cancer that develops after ADT. It is not known whether there is an enclave of androgeninsensitive cells within the primary tumor or whether the lack of androgens during ADT drives the tumor to acquire mutations and amplifications in the $A R$, allowing ligandindependent signaling. Recent studies indicate that there may be a population of androgen-insensitive cells within primary prostate tumors using the xenografts of clinical tumors in mice (Lawrence et al. 2013, Toivanen et al. 2013). The AR itself adapts to the sudden lack of androgens by increasing the number of receptors in the cell so that any available androgens are readily bound or by becoming hypersensitive to ligands that may be scarce (Chen et al. 2004, Taplin 2008). Mutations in the $A R$ gene are much more frequent in metastatic tumors than in primary tumors, indicating that mutations may be adaptive (Taplin et al. 1995, 1999). Deep sequencing of tumor samples from patients with CRPC revealed that cells may acquire novel

Published by Bioscientifica Ltd. 
mechanisms of AR synthesis and signaling, which will undoubtedly have significant effects on stromal-epithelial interactions (Grasso et al. 2012).

\section{AR-positive breast cancer}

AR status in breast cancer has only more recently been examined in relevance to treatment, although studies have shown that $\mathrm{AR}$ is the most common nuclear steroid receptor in breast tumors. Some data indicate that AR is more abundant in malignant mammary tissue than ER $\alpha$ (Lea et al. 1989, Isola 1993, Schippinger et al. 2006, Hanley et al. 2008, Park et al. 2010). Androgen treatment has yielded conflicting proliferation results in classic breast cancer cell lines, which indicates that the mechanistic role of AR in breast tumors is more complex (Birrell et al. 1995). In ER-positive breast tumors, AR levels dramatically decrease when treated with an aromatase inhibitor, when compared with those observed on treatment with the inhibitor in addition to tamoxifen (Harvell et al. 2008). Also, when excluding basal tumors, ER-negative breast cancer cells nearly always express AR, giving a possible therapeutic treatment target (Farmer et al. 2005). Enzalutamide, an AR antagonist used clinically in the treatment of prostate cancer patients, has been reported to be a possible endocrine therapy option. Treatment response has been linked to the ratio of AR:ER in the tumor (Cochrane et al. 2014). For these reasons, some have adopted a new breast cancer classification based solely on the ER and AR status of the tumor. Basal breast cancer is ER-negative/AR-negative, luminal breast cancer is ER-positive/AR-positive, and apocrine breast cancer is ER-negative/AR-positive. These apocrine tumors share AR-associated transcriptional characteristics of prostate cancer (Farmer et al. 2005).

The expression of AR in triple-negative breast cancer (TNBC) cells has been reported to be associated with a decrease in the expression of E-cadherin (Tang et al. 2012). The expression of AR and E-cadherin may be a strong indicator of chemotherapeutic response (Koo et al. 2009). Further study has shown that AR can directly repress E-cadherin in breast cancer, indicating that it contributes to EMT and metastasis. In the context of TNBC, Graham et al. (2010) demonstrated that zinc-finger binding protein 1 (ZEB1) and AR cross-talk to regulate EMT. The expression of ZEB1 and AR is increased in TNBC patients. Further data are available regarding the expression of AR in metastases as well as PSA levels correlating with tumor grade (Garay \& Park 2012, Hickey et al. 2012), but there are very few data regarding the role of stromal-epithelial interactions.
These studies highlight the importance of AR in the regulation of tumorigenesis in both breast and prostate cancers via epithelial-mesenchymal signaling. They also highlight potential therapeutic targets in these tumors. Presumably, a similar role for AR signaling and epithelial-mesenchymal interactions in tumorigenesis of other glandular derived carcinomas, such as salivary gland cancer, will be discovered with appropriate inquiry.

\section{Signaling pathways}

There are many androgen-regulated signaling networks in prostate cancer or signaling pathways that impinge on AR signaling; some of the major pathways are described below. We describe some specific examples below and show their relationships in a simple schematic form in Fig. 1.

\section{Fibroblast growth factor}

Members of the FGF family are found in the adult human prostate stroma, specifically FGF2, FGF7, and FGF9, in relatively high quantities (Giri et al. 1999). FGF10 is found in smaller quantities in the adult stroma, but plays a major role in development (Ropiquet et al. 2000). The ventralmesenchymal pad cells have been suggested as a model to examine FGF10 signaling in vitro. This model retains AR expression and has shown that FGF10 is regulated by TGF $\beta$ (Tomlinson et al. 2004). The expression of AR in the epithelium was shown to increase with higher FGF10 activity, and overexpression in mice results in prostate cancer (Memarzadeh et al. 2007). The expression of AR in the epithelium is required for stromal FGF10-induced PIN in vivo (Memarzadeh et al. 2011).

Findings regarding FGF7 have been particularly controversial; there have been conflicting studies showing that it may have either a direct or an indirect role in androgen signaling. For example, it was suggested that AR could mediate the upregulation of FGF7 (Yan et al. 1992, Nemeth et al. 1998, Planz et al. 1998, Giri \& Ittmann 2000). This would be important in the context of prostate cancer because embryology studies have shown that FGF7 is a potent stimulator of epithelial growth and may assist androgens in early prostate growth (Hom et al. 1998). FGF7 can bypass AR-dependent growth, indicating a possible role in CRPC (Ishii et al. 2009). In the context of the stromal fibroblast ARKO mouse, FGF7 and FGF10 levels are reduced. This is associated with decreased epithelial proliferation and has been suggested as a possible therapeutic target

Published by Bioscientifica Ltd. 
(Yu et al. 2013). The secretion of FGF7 is substantially higher in the cancer-associated peripheral zone than in the BPH-associated transitional zone (Jiang et al. 2011). Though further investigation is necessary to understand the exact role that FGF7 plays in prostate cancer cells, it is clear that the levels of FGF receptors are elevated and linked to androgen-dependent transcription, potentially through the MAPK pathway (Culig et al. 1994, Rowan et al. 2000, Debes et al. 2003).

\section{Hedgehog}

The Hedgehog (Hh) pathway has been reported to be involved in prostatic development, specifically in ductal branching. Mutations in the downstream target, sonic Hh (Shh), result in embryos without prostates. However, this is rescued when the pregnant females are treated with androgens, implicating $\mathrm{Hh}$ to be a major mediator of differentiation through stromal-epithelial interactions and the AR (Culig et al. 1994, Rowan et al. 2000, Debes et al. 2003). EMT is involved in prostate cancer progression and Hh plays a major role in this process (Huber et al. 2005). SHH has been suggested as a potential therapeutic target to prevent androgen-insensitive tumor progression, especially bone metastases, in prostate cancer (Shigemura et al. 2011). Additionally, members of the Hh pathway have been found preferentially in undifferentiated basal cells, which indicates that $\mathrm{Hh}$ is involved in stem/progenitor cell maintenance (Chen et al. 2007). Hh is active in both normal human prostate and prostate tumor stroma, and its downstream targets are upregulated in human prostatic fibroblasts. Smoothened (Smo), a downstream target of $\mathrm{Hh}$, is particularly necessary for the survival of CAFs (Wilkinson et al. 2013).

\section{Insulin-like growth factor 1}

IGF1 is produced in the prostatic stroma, stimulated by androgens. The increase in IGF1 levels has a proproliferative effect on the surrounding epithelia (Moschos \& Mantzoros 2002, Bogdanos et al. 2003, Garrison \& Kyprianou 2004). Reciprocally, androgens enhance the levels of IGF receptor and IGF1 promotes the production of steroid receptors (Culig et al. 1994). The inhibition of IGF1 receptor causes the nuclear AR to relocate to the cytoplasm, with subsequent transcriptional consequences for AR-mediated gene activity (York et al. 2005, Wu et al. 2006). Stromal ARKO mice exhibit reduced IGF1 expression. Lowered IGF1 expression in the stroma has been reported to be associated with a reduction in epithelial proliferation and maintenance (Yu et al. 2013). IGF1 has been implicated in CRPC, but IGF1-mediated growth may also affect androgens by promoting ligandindependent androgen action (Mantzoros et al. 1997). Circulating IGF1 is associated with a higher risk of prostate cancer as well as other types of cancers (Sachdev \& Yee 2007). Growth hormone-releasing hormone antagonists in conjunction with ADT have yielded promising therapeutic results by reducing IGF1 levels (Sciarra et al. 2008).

\section{Transforming growth factor beta}

TGF $\beta$ is produced by the stroma and is normally involved in tumor-suppressive activity by inducing epithelial apoptosis and controlling growth (Massague et al. 1992). As has been stated previously, TGF $\beta$ promotes stromal myodifferentiation via the $A R$, which may involve the translocation of AR to the nucleus. Myodifferentiation is of particular interest in stromal-epithelial interactions because an increase in the number of myofibroblasts can facilitate angiogenesis (Gerdes et al. 2004). The formation of myofibroblasts is associated with an androgen-mediated Hic5 nuclear translocation. Hic5 then alters the expression of AR target genes to make the microenvironment less favorable for migration and invasion. As has been described previously, the presence of the stromal AR in this context would be favorable (Leach et al. 2014). After ADT, TGF $\beta$-mediated apoptosis is responsible for a dramatic reduction in PSA levels as well as tumorigenicity (Guo \& Kyprianou 1999, Wikstrom et al. 1999). For example, the expression of TGF $\beta$ in CAFs is elevated and is associated with a greater capacity for colony formation in vitro (San Francisco et al. 2004). Furthermore, the TGF $\beta$ accessory receptor, endoglin, has been shown to promote the tumorigenicity of CAFs (Kim et al. 2013). In the context of the pes-ARKO mouse, TGF $\beta 1$ has been suggested as a mediator of EMT (Niu et al. 2008). TGF $\beta$ indirectly enhances the transcription of $A R$ via Smad3 and Smad4, but the exact mechanism is not well understood (Massague \& Chen 2000).

\section{Vascular endothelial growth factor}

Vascular endothelial growth factor (VEGF (VEGFA)) is a critical mediator of angiogenesis. Its expression is indirectly upregulated in prostate cancer stroma by the $\mathrm{AR}$, thus facilitating angiogenesis. Normally, VEGF is only found in fetal stroma when angiogenesis is necessary for

Published by Bioscientifica Ltd. 
normal development. VEGF is not found in BPH stroma, and its expression is upregulated, at both the mRNA and protein levels, by DHT treatment of cancer stroma in vitro (Levine et al. 1998). Therefore, it is not surprising that ADT downregulates the expression of stromal VEGF (Cheng et al. 2004). This improvement is not long lasting, however, and the expression of VEGF is upregulated again in CRPC cells (Pan et al. 2013). IGF and TGF $\beta$ upregulate the expression of VEGF transcriptionally (Eisermann et al. 2013, Li et al. 2013). There are currently multiple VEGF inhibitors in clinical use, as well as dual hepatocyte growth factor (MET) (an important signaling pathway in bone) and VEGF inhibitors currently being explored (Lee \& Smith 2013).

\section{WNT}

Wnt signaling through $\beta$-catenin is necessary for lineagespecific growth in the normal prostate (Memarzadeh et al. 2007). In the mouse embryo, Wnt/ $\beta$-catenin signaling is required for the normal development of the genital tubercle (Miyagawa et al. 2009). The Wnt pathway has been implicated in the self-renewal of prostate cancer cells, and its action combined with AR may be a driving force behind rapid renewal and differentiation (Bisson \& Prowse 2009). Furthermore, Wnt signaling inhibits E-cadherin and is involved in EMT (Liebner et al. 2004). Wnt signaling also seems to have an important role in androgen deprivation, wherein it is upregulated during ADT, but downregulated if androgens are added back. This, along with the self-renewal properties described, indicates that Wnt signaling may be vital for the treatment of CRPC patients (Prins \& Putz 2008). WNT11 protein is expressed in prostate cancer cells, and there is evidence that this protein is a mediator of invasion and migration as well as more aggressive neuroendocrine differentiation (Uysal-Onganer et al. 2010).

AR mediates Wnt signaling in breast cancer cells. Ni et al. (2011) showed that AR transcriptionally activates the Wnt and Her2 pathways in a ligand-dependent manner. This indicates a possible role for AR therapeutic targeting in Her2-positive breast cancer.

Clearly, numerous ligands and their receptors are important for mediating the effects of AR signaling on epithelial-mesenchymal interactions in the normal development and tumorigenesis of both breast and prostate cancer cells. These are prime targets for intervention to disrupt feed-forward signaling pathways that drive tumorigenesis.

\section{Conclusions}

Based on the information reported herein, it is clear that stromal-epithelial interactions have major effects on androgen action in both prostate cancer and breast cancer. AR signaling is both temporally and spatially regulated throughout development. Normal prostate and breast organization continue to be dependent on the expression of AR throughout adult life. There is evidence that the expression of AR is linked to prostate cancer progression, but the role of $\mathrm{AR}$ in breast cancer progression is not known. The inductive action of prostatic stroma is undeniable, and it is a major void in our understanding of prostate cancer. The genomic effect of CAFs is still not known. There is a pressing need for therapeutic targets for preventing CRPC or treating CRPC patients, and stromalepithelial interactions are a likely candidate. Our knowledge of AR expression in breast cancer cells is growing, but the role of stromal-epithelial interactions is unclear. AR-dependent signaling pathways have been well established in prostate cancer patients, but are only marginally understood in breast cancer patients. Discoveries reported herein could lead to new endocrine therapeutic targets in both sets of cancer patients. Future work should also be focused on the role of AR in epithelialmesenchymal reciprocal signaling in other tissues. These studies may lead to a more comprehensive understanding of the roles of AR signaling in normal development and its misregulation in diseases such as cancer.

\section{Declaration of interest}

The authors declare that there is no conflict of interest that could be perceived as prejudicing the impartiality of the review.

\section{Funding}

This work was supported in part by NIH grants R01-CA129418 and R01-CA150105

\section{References}

Ao M, Franco OE, Park D, Raman D, Williams K \& Hayward SW 2007 Crosstalk between paracrine-acting cytokine and chemokine pathways promotes malignancy in benign human prostatic epithelium. Cancer Research 67 4244-4253. (doi:10.1158/0008-5472.CAN-06-3946)

Barclay WW, Woodruff RD, Hall MC \& Cramer SD 2005 A system for studying epithelial-stromal interactions reveals distinct inductive abilities of stromal cells from benign prostatic hyperplasia and prostate cancer. Endocrinology 146 13-18. (doi:10.1210/en.2004-1123)

Barron DA \& Rowley DR 2012 The reactive stroma microenvironment and prostate cancer progression. Endocrine-Related Cancer 19 R187-R204. (doi:10.1530/ERC-12-0085)

Published by Bioscientifica Ltd. 
Bauman TM, Sehgal PD, Johnson KA, Pier T, Bruskewitz RC, Ricke WA \& Huang W 2014 Finasteride treatment alters tissue specific androgen receptor expression in prostate tissues. Prostate 74 923-932. (doi:10.1002/pros.22810)

Birrell SN, Bentel JM, Hickey TE, Ricciardelli C, Weger MA, Horsfall DJ \& Tilley WD 1995 Androgens induce divergent proliferative responses in human breast cancer cell lines. Journal of Steroid Biochemistry and Molecular Biology 52 459-467. (doi:10.1016/0960-0760(95) 00005-K)

Bisson I \& Prowse DM 2009 WNT signaling regulates self-renewal and differentiation of prostate cancer cells with stem cell characteristics. Cell Research 19 683-697. (doi:10.1038/cr.2009.43)

Bogdanos J, Karamanolakis D, Tenta R, Tsintavis A, Milathianakis C, Mitsiades C \& Koutsilieris M 2003 Endocrine/paracrine/autocrine survival factor activity of bone microenvironment participates in the development of androgen ablation and chemotherapy refractoriness of prostate cancer metastasis in skeleton. Endocrine-Related Cancer $\mathbf{1 0}$ 279-289. (doi:10.1677/erc.0.0100279)

Boutin EL \& Cunha GR 1997 Estrogen-induced epithelial proliferation and cornification are uncoupled in sinus vaginal epithelium associated with uterine stroma. Differentiation 62 171-178. (doi:10.1046/j.1432-0436. 1998.6240171.x)

Brossner C, Winterholer A, Roehlich M, Dlouhy-Schutz E, Serra V, Sonnleithner M, Grubmuller KH, Pummer K \& Schuster E 2003 Distribution of prostate carcinoma foci within the peripheral zone: analysis of 8,062 prostate biopsy cores. World Journal of Urology $\mathbf{2 1}$ 163-166. (doi:10.1007/s00345-003-0341-4)

Cano P, Godoy A, Escamilla R, Dhir R \& Onate SA 2007 Stromal-epithelial cell interactions and androgen receptor-coregulator recruitment is altered in the tissue microenvironment of prostate cancer. Cancer Research 67 511-519. (doi:10.1158/0008-5472.CAN-06-1478)

Chang C, Lee SO, Yeh S \& Chang TM 2014 Androgen receptor (AR) differential roles in hormone-related tumors including prostate, bladder, kidney, lung, breast and liver. Oncogene 33 3225-3234. (doi:10.1038/onc.2013.274)

Chen CD, Welsbie DS, Tran C, Baek SH, Chen R, Vessella R, Rosenfeld MG \& Sawyers CL 2004 Molecular determinants of resistance to antiandrogen therapy. Nature Medicine 10 33-39. (doi:10.1038/nm972) (doi:10.1038/nm972)

Chen BY, Liu JY, Chang HH, Chang CP, Lo WY, Kuo WH, Yang CR \& Lin DP 2007 Hedgehog is involved in prostate basal cell hyperplasia formation and its progressing towards tumorigenesis. Biochemical and Biophysical Research Communications 357 1084-1089. (doi:10.1016/ j.bbrc.2007.04.091)

Cheng L, Zhang S, Sweeney CJ, Kao C, Gardner TA \& Eble JN 2004 Androgen withdrawal inhibits tumor growth and is associated with decrease in angiogenesis and VEGF expression in androgen-independent CWR22Rv1 human prostate cancer model. Anticancer Research $\mathbf{2 4}$ 2135-2140.

Cochrane DR, Bernales S, Jacobsen BM, Cittelly DM, Howe EN, D Amato NC, Spoelstra NS, Edgerton SM, Jean A, Guerrero J et al. 2014 Role of the androgen receptor in breast cancer and preclinical analysis of enzalutamide. Breast Cancer Research 16 R7. (doi:10.1186/ bcr3599)

Culig Z, Hobisch A, Cronauer MV, Radmayr C, Trapman J, Hittmair A, Bartsch G \& Klocker H 1994 Androgen receptor activation in prostatic tumor cell lines by insulin-like growth factor-I, keratinocyte growth factor, and epidermal growth factor. Cancer Research $\mathbf{5 4}$ 5474-5478.

Cunha GR 1972 Epithelio-mesenchymal interactions in primordial gland structures which become responsive to androgenic stimulation. Anatomical Record 172 179-195. (doi:10.1002/ar.1091720206)

Cunha GR 1984 Androgenic effects upon prostatic epithelium are mediated via trophic influences from stroma. Progress in Clinical and Biological Research 145 81-102.
Cunha GR \& Chung LW 1981 Stromal-epithelial interactions. I. Induction of prostatic phenotype in urothelium of testicular feminized ( $\mathrm{Tfm} / \mathrm{y}$ ) mice. Journal of Steroid Biochemistry 14 1317-1324. (doi:10.1016/00224731(81)90338-1)

Cunha GR \& Lung B 1978 The possible influence of temporal factors in androgenic responsiveness of urogenital tissue recombinants from wild-type and androgen-insensitive (Tfm) mice. Journal of Experimental Zoology 205 181-193. (doi:10.1002/jez.1402050203)

Cunha GR, Fujii H, Neubauer BL, Shannon JM, Sawyer L \& Reese BA 1983 Epithelial-mesenchymal interactions in prostatic development. I. Morphological observations of prostatic induction by urogenital sinus mesenchyme in epithelium of the adult rodent urinary bladder. Journal of Cell Biology 96 1662-1670. (doi:10.1083/jcb.96.6.1662)

Cunha GR, Donjacour AA, Cooke PS, Mee S, Bigsby RM, Higgins SJ \& Sugimura Y 1987 The endocrinology and developmental biology of the prostate. Endocrine Reviews 8 338-362. (doi:10.1210/edrv-83-338)

Debes JD, Sebo TJ, Lohse CM, Murphy LM, Haugen DA \& Tindall DJ 2003 p300 in prostate cancer proliferation and progression. Cancer Research 63 7638-7640.

De Gendt K, Swinnen JV, Saunders PT, Schoonjans L, Dewerchin M, Devos A, Tan K, Atanassova N, Claessens F, Lecureuil C et al. 2004 A Sertoli cell-selective knockout of the androgen receptor causes spermatogenic arrest in meiosis. PNAS 101 1327-1332. (doi:10.1073/ pnas.0308114100)

Donjacour AA \& Cunha GR 1993 Assessment of prostatic protein secretion in tissue recombinants made of urogenital sinus mesenchyme and urothelium from normal or androgen-insensitive mice. Endocrinology 132 2342-2350. (doi:10.1210/endo.132.6.7684975)

Donjacour AA \& Cunha GR 1995 Induction of prostatic morphology and secretion in urothelium by seminal vesicle mesenchyme. Development 121 2199-2207.

Durnberger H \& Kratochwil K 1980 Specificity of tissue interaction and origin of mesenchymal cells in the androgen response of the embryonic mammary gland. Cell 19 465-471. (doi:10.1016/0092-8674 (80)90521-8)

Dvorak HF 1986 Tumors: wounds that do not heal. Similarities between tumor stroma generation and wound healing. New England Journal of Medicine 315 1650-1659. (doi:10.1056/NEJM198612253 152606)

Eisermann K, Broderick CJ, Bazarov A, Moazam MM \& Fraizer GC 2013 Androgen up-regulates vascular endothelial growth factor expression in prostate cancer cells via an Sp1 binding site. Molecular Cancer 127. (doi:10.1186/1476-4598-12-7)

Farmer P, Bonnefoi H, Becette V, Tubiana-Hulin M, Fumoleau P, Larsimont D, Macgrogan G, Bergh J, Cameron D, Goldstein D et al. 2005 Identification of molecular apocrine breast tumours by microarray analysis. Oncogene 24 4660-4671. (doi:10.1038/sj.onc.1208561)

Feneley MR, Puddefoot JR, Xia S, Sowter C, Slavin G, Kirby RS \& Vinson GP 1995 Zonal biochemical and morphological characteristics in BPH. British Journal of Urology 75 608-613. (doi:10.1111/j.1464-410X.1995. tb07418.x)

Fiaschi T, Marini A, Giannoni E, Taddei ML, Gandellini P, De Donatis A Lanciotti M, Serni S, Cirri P \& Chiarugi P 2012 Reciprocal metabolic reprogramming through lactate shuttle coordinately influences tumor-stroma interplay. Cancer Research 72 5130-5140. (doi:10.1158/ 0008-5472.CAN-12-1949)

Frank SB \& Miranti CK 2013 Disruption of prostate epithelial differentiation pathways and prostate cancer development. Frontiers in Oncology 3 273. (doi:10.3389/fonc.2013.00273)

Gao J, Arnold JT \& Isaacs JT 2001 Conversion from a paracrine to an autocrine mechanism of androgen-stimulated growth during malignant transformation of prostatic epithelial cells. Cancer Research $\mathbf{6 1}$ 5038-5044.

Garay JP \& Park BH 2012 Androgen receptor as a targeted therapy for breast cancer. American Journal of Cancer Research 2 434-445. 
Garrison JB \& Kyprianou N 2004 Novel targeting of apoptosis pathways for prostate cancer therapy. Current Cancer Drug Targets 4 85-95. (doi:10.2174/1568009043481623)

Gerdes MJ, Larsen M, Dang TD, Ressler SJ, Tuxhorn JA \& Rowley DR 2004 Regulation of rat prostate stromal cell myodifferentiation by androgen and TGF- $\beta 1$. Prostate 58 299-307. (doi:10.1002/pros.10327)

Giri D \& Ittmann M 2000 Interleukin- $1 \alpha$ is a paracrine inducer of FGF7, a key epithelial growth factor in benign prostatic hyperplasia. American Journal of Pathology 157 249-255. (doi:10.1016/S0002-9440(10)64535-X)

Giri D, Ropiquet F \& Ittmann M 1999 Alterations in expression of basic fibroblast growth factor (FGF) 2 and its receptor FGFR-1 in human prostate cancer. Clinical Cancer Research 5 1063-1071.

Graham TR, Yacoub R, Taliaferro-Smith L, Osunkoya AO, Odero-Marah VA, Liu T, Kimbro KS, Sharma D \& O'Regan RM 2010 Reciprocal regulation of ZEB1 and AR in triple negative breast cancer cells. Breast Cancer Research and Treatment 123 139-147. (doi:10.1007/ s10549-009-0623-7)

Grasso CS, Wu YM, Robinson DR, Cao X, Dhanasekaran SM, Khan AP, Quist MJ, Jing X, Lonigro RJ, Brenner JC et al. 2012 The mutationa landscape of lethal castration-resistant prostate cancer. Nature $\mathbf{4 8 7}$ 239-243. (doi:10.1038/nature11125)

Grignon DJ \& Sakr WA 1994 Zonal origin of prostatic adenocarcinoma: are there biologic differences between transition zone and peripheral zone adenocarcinomas of the prostate gland? Journal of Cellular Biochemistry. Supplement 19 267-269.

Guo Y \& Kyprianou N 1999 Restoration of transforming growth factor $\beta$ signaling pathway in human prostate cancer cells suppresses tumorigenicity via induction of caspase-1-mediated apoptosis. Cancer Research 59 1366-1371.

Hanley K, Wang J, Bourne P, Yang Q, Gao AC, Lyman G \& Tang P 2008 Lack of expression of androgen receptor may play a critical role in transformation from in situ to invasive basal subtype of high-grade ductal carcinoma of the breast. Human Pathology 39 386-392. (doi:10.1016/j.humpath.2007.07.007)

Harvell DM, Richer JK, Singh M, Spoelstra N, Finlayson C, Borges VF, Elias AD \& Horwitz KB 2008 Estrogen regulated gene expression in response to neoadjuvant endocrine therapy of breast cancers: tamoxifen agonist effects dominate in the presence of an aromatase inhibitor. Breast Cancer Research and Treatment 112 489-501. (doi:10.1007/s10549-008-9923-6)

Hayward SW, Baskin LS, Haughney PC, Cunha AR, Foster BA, Dahiya R, Prins GS \& Cunha GR 1996 Epithelial development in the rat ventral prostate, anterior prostate and seminal vesicle. Acta Anatomica 155 81-93. (doi:10.1159/000147793)

Hayward SW, Wang Y, Cao M, Hom YK, Zhang B, Grossfeld GD, Sudilovsky D \& Cunha GR 2001 Malignant transformation in a nontumorigenic human prostatic epithelial cell line. Cancer Research $\mathbf{6 1}$ 8135-8142.

He Y, Franco OE, Jiang M, Williams K, Love HD, Coleman IM, Nelson PS \& Hayward SW 2007 Tissue-specific consequences of cyclin D1 overexpression in prostate cancer progression. Cancer Research $\mathbf{6 7}$ 8188-8197. (doi:10.1158/0008.5472.CAN-07-0418)

Henshall SM, Quinn DI, Lee CS, Head DR, Golovsky D, Brenner PC, Delprado W, Stricker PD, Grygiel JJ \& Sutherland RL 2001 Altered expression of androgen receptor in the malignant epithelium and adjacent stroma is associated with early relapse in prostate cancer. Cancer Research 61 423-427.

Heuberger B, Fitzka I, Wasner G \& Kratochwil K 1982 Induction of androgen receptor formation by epithelium-mesenchyme interaction in embryonic mouse mammary gland. PNAS 79 2957-2961. (doi:10.1073/pnas.79.9.2957)

Hickey TE, Robinson JL, Carroll JS \& Tilley WD 2012 Minireview: The androgen receptor in breast tissues: growth inhibitor, tumor suppressor, oncogene? Molecular Endocrinology 26 1252-1267. (doi:10.1210/me.2012-1107)

Holdcraft RW \& Braun RE 2004 Androgen receptor function is required in Sertoli cells for the terminal differentiation of haploid spermatids. Development 131 459-467. (doi:10.1242/dev.00957)
Hom YK, Young P, Thomson AA \& Cunha GR 1998 Keratinocyte growth factor injected into female mouse neonates stimulates uterine and vaginal epithelial growth. Endocrinology 139 3772-3779. (doi:10.1210/ endo.139.9.6182)

Hsieh CL, Gardner TA, Miao L, Balian G \& Chung LW 2004 Cotargeting tumor and stroma in a novel chimeric tumor model involving the growth of both human prostate cancer and bone stromal cells. Cancer Gene Therapy 11 148-155. (doi:10.1038/sj.cgt.7700665)

Huber MA, Kraut N \& Beug H 2005 Molecular requirements for epithelialmesenchymal transition during tumor progression. Current Opinion in Cell Biology 17 548-558. (doi:10.1016/j.ceb.2005.08.001)

Huggins C \& Clark PJ 1940 Quantitative studies of prostatic secretion: II. The effect of castration and of estrogen injection on the normal and on the hyperplastic prostate glands of dogs. Journal of Experimental Medicine 72 747-762. (doi:10.1084/jem.72.6.747)

Huggins C \& Sommer JL 1953 Quantitative studies of prostatic secretion. III. Simultaneous measurement of size and secretion of the canine prostate and the interaction of androgenic and estrogenic substances thereon. Journal of Experimental Medicine 97 663-680. (doi:10.1084/jem.97.5.663)

Huggins C, Masina MH, Eichelberger L \& Wharton JD 1939 Quantitative studies of prostatic secretion: I. Characteristics of the normal secretion; the influence of thyroid, suprarenal, and testis extirpation and androgen substitution on the prostatic output. Journal of Experimental Medicine 70 543-556. (doi:10.1084/jem.70.6.543)

Ishii K, Imamura T, Iguchi K, Arase S, Yoshio Y, Arima K, Hirano K \& Sugimura Y 2009 Evidence that androgen-independent stromal growth factor signals promote androgen-insensitive prostate cancer cell growth in vivo. Endocrine-Related Cancer 16 415-428. (doi:10.1677/ERC-08-0219)

Isola JJ 1993 Immunohistochemical demonstration of androgen receptor in breast cancer and its relationship to other prognostic factors. Journal of Pathology 170 31-35. (doi:10.1002/path.1711700106)

Jiang Q, Han BM, Zhao FJ, Hong Y \& Xia SJ 2011 The differential effects of prostate stromal cells derived from different zones on prostate cancer epithelial cells under the action of sex hormones. Asian Journal of Andrology 13 798-805. (doi:10.1038/aja.2011.22)

Kim SK, Romero R, Savasan ZA, Xu Y, Dong Z, Lee DC, Yeo L, Hassan SS \& Chaiworapongsa T 2013 Endoglin in amniotic fluid as a risk factor for the subsequent development of bronchopulmonary dysplasia. American Journal of Reproductive Immunology 69 105-123. (doi:10.1111/aji.12046)

Koo JS, Jung W \& Jeong J 2009 The predictive role of E-cadherin and androgen receptor on in vitro chemosensitivity in triple-negative breast cancer. Japanese Journal of Clinical Oncology 39 560-568. (doi:10.1093/ jjco/hyp065)

Kratochwil K 1969 Organ specificity in mesenchymal induction demonstrated in the embryonic development of the mammary gland of the mouse. Developmental Biology 20 46-71. (doi:10.1016/00121606(69)90004-9)

Kratochwil K \& Schwartz P 1976 Tissue interaction in androgen response of embryonic mammary rudiment of mouse: identification of target tissue for testosterone. PNAS 73 4041-4044. (doi:10.1073/pnas.73.11.4041)

Kurita T, Wang YZ, Donjacour AA, Zhao C, Lydon JP, O'Malley BW, Isaacs JT, Dahiya R \& Cunha GR 2001 Paracrine regulation of apoptosis by steroid hormones in the male and female reproductive system. Cell Death and Differentiation 8 192-200. (doi:10.1038/sj.cdd.4400797)

Lai KP, Yamashita S, Huang CK, Yeh S \& Chang C 2012 Loss of stromal androgen receptor leads to suppressed prostate tumourigenesis via modulation of pro-inflammatory cytokines/chemokines. EMBO Molecular Medicine 4 791-807. (doi:10.1002/emmm.201101140)

Lawrence MG, Taylor RA, Toivanen R, Pedersen J, Norden S, Pook DW, Frydenberg M, Australian Prostate Cancer BioResource, Papargiris MM, Niranjan B et al. 2013 A preclinical xenograft model of prostate cancer using human tumors. Nature Protocols 8 836-848. (doi:10.1038/nprot. 2013.043)

Lea OA, Kvinnsland S \& Thorsen T 1989 Improved measurement of androgen receptors in human breast cancer. Cancer Research 49 7162-7167. 
Leach DA, Need EF, Trotta AP, Grubisha MJ, Defranco DB \& Buchanan G 2014 Hic-5 influences genomic and non-genomic actions of the androgen receptor in prostate myofibroblasts. Molecular and Cellular Endocrinology 384 185-199. (doi:10.1016/j.mce.2014.01.004)

Lee SO, Tian J, Huang CK, Ma Z, Lai KP, Hsiao H, Jiang M, Yeh S \& Chang C 2012 Suppressor role of androgen receptor in proliferation of prostate basal epithelial and progenitor cells. Journal of Endocrinology $\mathbf{2 1 3}$ 173-182. (doi:10.1530/JOE-11-0474)

Lee RJ \& Smith MR 2013 Targeting MET and vascular endothelial growth factor receptor signaling in castration-resistant prostate cancer. Cancer Journal 19 90-98. (doi:10.1097/PPO.0b013e318281e280)

Levine AC, Liu XH, Greenberg PD, Eliashvili M, Schiff JD, Aaronson SA, Holland JF \& Kirschenbaum A 1998 Androgens induce the expression of vascular endothelial growth factor in human fetal prostatic fibroblasts. Endocrinology 139 4672-4678. (doi:10.1210/endo.139. 11.6303)

Li X, Feng Y, Liu J, Feng X, Zhou K \& Tang X 2013 Epigallocatechin-3gallate inhibits IGF-I-stimulated lung cancer angiogenesis through downregulation of HIF- $1 \alpha$ and VEGF expression. Journal of Nutrigenetics and Nutrigenomics 6 169-178. (doi:10.1159/000354402)

Liebner S, Cattelino A, Gallini R, Rudini N, Iurlaro M, Piccolo S \& Dejana E $2004 \beta$-Catenin is required for endothelial-mesenchymal transformation during heart cushion development in the mouse. Journal of Cell Biology 166 359-367. (doi:10.1083/jcb.200403050)

Lin-Tsai O, Clark PE, Miller NL, Fowke JH, Hameed O, Hayward SW \& Strand DW 2014 Surgical intervention for symptomatic benign prostatic hyperplasia is correlated with expression of the AP-1 transcription factor network. Prostate 74 669-679. (doi:10.1002/pros.22785)

Love HD, Booton SE, Boone BE, Breyer JP, Koyama T, Revelo MP, Shappell SB, Smith JR \& Hayward SW 2009 Androgen regulated genes in human prostate xenografts in mice: relation to BPH and prostate cancer. PLoS ONE 4 e8384. (doi:10.1371/journal.pone.0008384)

Mantzoros CS, Tzonou A, Signorello LB, Stampfer M, Trichopoulos D \& Adami HO 1997 Insulin-like growth factor 1 in relation to prostate cancer and benign prostatic hyperplasia. British Journal of Cancer $\mathbf{7 6}$ 1115-1118. (doi:10.1038/bjc.1997.520)

Massague J \& Chen YG 2000 Controlling TGF- $\beta$ signaling. Genes and Development 14 627-644.

Massague J, Cheifetz S, Laiho M, Ralph DA, Weis FM \& Zentella A 1992 Transforming growth factor- $\beta$. Cancer Surveys 12 81-103.

Matsumoto T, Takeyama K, Sato T \& Kato S 2003 Androgen receptor functions from reverse genetic models. Journal of Steroid Biochemistry and Molecular Biology 85 95-99. (doi:10.1016/S0960-0760(03)00231-0)

McNeal J 1990 Pathology of benign prostatic hyperplasia. Insight into etiology. Urologic Clinics of North America 17 477-486.

McNeal JE, Redwine EA, Freiha FS \& Stamey TA 1988 Zonal distribution of prostatic adenocarcinoma. Correlation with histologic pattern and direction of spread. American Journal of Surgical Pathology 12 897-906.

Meeks JJ \& Schaeffer EM 2011 Genetic regulation of prostate development. Journal of Andrology 32 210-217. (doi:10.2164/jandrol.110.011577)

Memarzadeh S, Xin L, Mulholland DJ, Mansukhani A, Wu H, Teitell MA \& Witte ON 2007 Enhanced paracrine FGF10 expression promotes formation of multifocal prostate adenocarcinoma and an increase in epithelial androgen receptor. Cancer Cell 12 572-585. (doi:10.1016/j. ccr.2007.11.002)

Memarzadeh S, Cai H, Janzen DM, Xin L, Lukacs R, Riedinger M, Zong Y DeGendt K, Verhoeven G, Huang J et al. 2011 Role of autonomous androgen receptor signaling in prostate cancer initiation is dichotomous and depends on the oncogenic signal. PNAS 108 7962-7967. (doi:10.1073/pnas.1105243108)

Miyagawa S, Satoh Y, Haraguchi R, Suzuki K, Iguchi T, Taketo MM, Nakagata N, Matsumoto T, Takeyama K, Kato S et al. 2009 Genetic interactions of the androgen and $\mathrm{Wnt} / \beta$-catenin pathways for the masculinization of external genitalia. Molecular Endocrinology 23 871-880. (doi:10.1210/me.2008-0478)
Moschos SJ \& Mantzoros CS 2002 The role of the IGF system in cancer: from basic to clinical studies and clinical applications. Oncology 63 317-332. (doi:10.1159/000066230)

Nemeth JA, Zelner DJ, Lang S \& Lee C 1998 Keratinocyte growth factor in the rat ventral prostate: androgen-independent expression. Journal of Endocrinology 156 115-125. (doi:10.1677/joe.0.1560115)

Ni M, Chen Y, Lim E, Wimberly H, Bailey ST, Imai Y, Rimm DL, Liu XS \& Brown M 2011 Targeting androgen receptor in estrogen receptor-negative breast cancer. Cancer Cell 20 119-131. (doi:10.1016/j.ccr.2011.05.026)

Nicholson TM, Sehgal PD, Drew SA, Huang W \& Ricke WA 2013 Sex steroid receptor expression and localization in benign prostatic hyperplasia varies with tissue compartment. Differentiation 85 140-149. (doi:10.1016/j.diff.2013.02.006)

Niu Y, Altuwaijri S, Yeh S, Lai KP, Yu S, Chuang KH, Huang SP, Lardy H \& Chang C 2008 Targeting the stromal androgen receptor in primary prostate tumors at earlier stages. PNAS 105 12188-12193. (doi:10.1073/ pnas.0804701105)

Niu Y, Wang J, Shang Z, Huang S-P, Shyr C-R, Yeh S \& Chang C 2011 Increased CK5/CK8-positive intermediate cells with stromal smooth muscle cell arophy in the mice lacking prostate epithelial androgen receptor. PLoS ONE 6 e20202. (doi:10.1371/journal.pone.0020202)

Notini AJ, Davey RA, McManus JF, Bate KL \& Zajac JD 2005 Genomic actions of the androgen receptor are required for normal male sexual differentiation in a mouse model. Journal of Molecular Endocrinology $\mathbf{3 5}$ 547-555. (doi:10.1677/jme.1.01884)

Olumi A, Grossfeld G, Hayward S, Carroll P, Tlsty T \& Cunha G 1999 Carcinoma-associated fribroblasts direct tumor progression of initiated human prostate epithelium. Cancer Research 59 5002-5011.

Pan L, Baek S, Edmonds PR, Roach M III, Wolkov H, Shah S, Pollack A, Hammond ME \& Dicker AP 2013 Vascular endothelial growth factor (VEGF) expression in locally advanced prostate cancer: secondary analysis of radiation therapy oncology group (RTOG) 8610. Radiation Oncology 8 100. (doi:10.1186/1748-717X-8-100)

Park S, Koo J, Park HS, Kim JH, Choi SY, Lee JH, Park BW \& Lee KS 2010 Expression of androgen receptors in primary breast cancer. Annals of Oncology 21 488-492. (doi:10.1093/annonc/mdp510)

Pavelic J, Zeljko Z \& Bosnar MH 2003 Molecular genetic aspects of prostate transition zone lesions. Urology 62 607-613.

Peters AA, Buchanan G, Ricciardelli C, Bianco-Miotto T, Centenera MM, Harris JM, Jindal S, Segara D, Jia L, Moore NL et al. 2009 Androgen receptor inhibits estrogen receptor- $\alpha$ activity and is prognostic in breast cancer. Cancer Research 69 6131-6140. (doi:10.1158/0008-5472.CAN-09-0452)

Peters AA, Ingman WV, Tilley WD \& Butler LM 2011 Differential effects of exogenous androgen and an androgen receptor antagonist in the peri- and postpubertal murine mammary gland. Endocrinology 152 3728-3737. (doi:10.1210/en.2011-1133)

Planz B, Wang Q, Kirley SD, Lin CW \& McDougal WS 1998 Androgen responsiveness of stromal cells of the human prostate: regulation of cell proliferation and keratinocyte growth factor by androgen. Journal of Urology 160 1850-1855. (doi:10.1016/S0022-5347(01)62431-5)

Prins GS \& Putz O 2008 Molecular signaling pathways that regulate prostate gland development. Differentiation 76 641-659. (doi:10.1111/j. 1432-0436.2008.00277.x)

Pruitt FL, He Y, Franco OE, Jiang M, Cates JM \& Hayward SW 2013 Cathepsin $\mathrm{D}$ acts as an essential mediator to promote malignancy of benign prostatic epithelium. Prostate 73 476-488. (doi:10.1002/pros.22589)

Ricciardelli C, Choong CS, Buchanan G, Vivekanandan S, Neufing P, Stahl J, Marshall VR, Horsfall DJ \& Tilley WD 2005 Androgen receptor levels in prostate cancer epithelial and peritumoral stromal cells identify nonorgan confined disease. Prostate 63 19-28. (doi:10.1002/pros.20154)

Ricke EA, Williams K, Lee YF, Couto S, Wang Y, Hayward SW, Cunha GR \& Ricke WA 2012 Androgen hormone action in prostatic carcinogenesis: stromal androgen receptors mediate prostate cancer progression, malignant transformation and metastasis. Carcinogenesis $\mathbf{3 3}$ 1391-1398. (doi:10.1093/carcin/bgs153) 
Ropiquet F, Giri D, Kwabi-Addo B, Schmidt K \& Ittmann M 2000 FGF-10 is expressed at low levels in the human prostate. Prostate 44 334-338. (doi:10.1002/1097-0045(20000901)44:4<334::AID-PROS11>3.0. CO;2-G)

Rowan BG, Weigel NL \& O'Malley BW 2000 Phosphorylation of steroid receptor coactivator-1. Identification of the phosphorylation sites and phosphorylation through the mitogen-activated protein kinase pathway. Journal of Biological Chemistry 275 4475-4483. (doi:10.1074/ jbc.275.6.4475)

Sachdev D \& Yee D 2007 Disrupting insulin-like growth factor signaling as a potential cancer therapy. Molecular Cancer Therapeutics 6 1-12. (doi:10.1158/1535-7163.MCT-06-0080)

San Francisco IF, DeWolf WC, Peehl DM \& Olumi AF 2004 Expression of transforming growth factor- $\beta 1$ and growth in soft agar differentiate prostate carcinoma-associated fibroblasts from normal prostate fibroblasts. International Journal of Cancer 112 213-218. (doi:10.1002/ijc. 20388)

Schippinger W, Regitnig P, Dandachi N, Wernecke KD, Bauernhofer T, Samonigg H \& Moinfar F 2006 Evaluation of the prognostic significance of androgen receptor expression in metastatic breast cancer. Virchows Archiv 449 24-30. (doi:10.1007/s00428-006-0213-6)

Sciarra A, Panebianco V, Ciccariello M, Salciccia S, Gentilucci A, Lisi D, Passariello R, Gentile V \& Di Silverio F 2008 Complete response to the combination therapy with androgen blockade and somatostatin analogue in a patient with advanced prostate cancer: magnetic resonance imaging with $1 \mathrm{H}$-spectroscopy. European Urology $\mathbf{5 3}$ 652-655. (doi:10.1016/j.eururo.2007.02.010)

Shannon JM \& Cunha GR 1984 Characterization of androgen binding and deoxyribonucleic acid synthesis in prostate-like structures induced in the urothelium of testicular feminized $(\mathrm{Tfm} / \mathrm{Y})$ mice. Biology of Reproduction 31 175-183. (doi:10.1095/biolreprod31.1.175)

Shao R, Shi J, Liu H, Shi X, Du X, Klocker H, Lee C, Zhu Y \& Zhang J 2014 Epithelial-to-mesenchymal transition and estrogen receptor $\alpha$ mediated epithelial dedifferentiation mark the development of benign prostatic hyperplasia. Prostate 74 970-982. (doi:10.1002/pros. 22814)

Shigemura K, Isotani S, Wang R, Fujisawa M, Gotoh A, Marshall FF, Zhau HE \& Chung LW 2009 Soluble factors derived from stroma activated androgen receptor phosphorylation in human prostate LNCaP cells: roles of ERK/MAP kinase. Prostate 69 949-955. (doi:10.1002/pros.20944)

Shigemura K, Huang WC, Li X, Zhau HE, Zhu G, Gotoh A, Fujisawa M, Xie J, Marshall FF \& Chung LW 2011 Active sonic hedgehog signaling between androgen independent human prostate cancer cells and normal/benign but not cancer-associated prostate stromal cells. Prostate 71 1711-1722. (doi:10.1002/pros.21388)

Shimazaki J, Kurihara H, Ito Y \& Shida K 1965 Metabolism of testosterone in prostate. 2 . Separation of prostatic 17- $\beta$-ol-dehydrogenase and 5- $\alpha$-reductase. Gunma Journal of Medical Sciences 14 326-333.

Simpson L \& Parsons R 2001 PTEN: life as a tumor suppressor. Experimental Cell Research 264 29-41. (doi:10.1006/excr.2000.5130)

Sugimura Y, Cunha GR \& Bigsby RM 1986 Androgenic induction of DNA synthesis in prostatic glands induced in the urothelium of testicular feminized (Tfm/Y) mice. Prostate 9 217-225.

Takeda H \& Chang C 1991 Immunohistochemical and in-situ hybridization analysis of androgen receptor expression during the development of the mouse prostate gland. Journal of Endocrinology 129 83-89.

Tang D, Xu S, Zhang Q \& Zhao W 2012 The expression and clinical significance of the androgen receptor and E-cadherin in triple-negative breast cancer. Medical Oncology 29 526-533. (doi:10.1007/s12032-0119948-2)

Tanner MJ, Welliver RC Jr, Chen M, Shtutman M, Godoy A, Smith G, Mian BM \& Buttyan R 2011 Effects of androgen receptor and androgen on gene expression in prostate stromal fibroblasts and paracrine signaling to prostate cancer cells. PLOS ONE 6 e16027. (doi:10.1371/journal.pone. 0016027)
Taplin ME 2008 Androgen receptor: role and novel therapeutic prospects in prostate cancer. Expert Review of Anticancer Therapy 8 1495-1508. (doi:10.1586/14737140.8.9.1495)

Taplin ME, Bubley GJ, Shuster TD, Frantz ME, Spooner AE, Ogata GK, Keer HN \& Balk SP 1995 Mutation of the androgen-receptor gene in metastatic androgen-independent prostate cancer. New England Journal of Medicine 332 1393-1398. (doi:10.1056/ NEJM199505253322101)

Taplin ME, Bubley GJ, Ko YJ, Small EJ, Upton M, Rajeshkumar B \& Balk SP 1999 Selection for androgen receptor mutations in prostate cancers treated with androgen antagonist. Cancer Research $\mathbf{5 9}$ 2511-2515.

Thalmann GN, Rhee H, Sikes RA, Pathak S, Multani A, Zhau HE, Marshall FF \& Chung LW 2010 Human prostate fibroblasts induce growth and confer castration resistance and metastatic potential in LNCaP Cells. European Urology 58 162-171. (doi:10.1016/j.eururo. 2009.08.026)

Toivanen R, Frydenberg M, Murphy D, Pedersen J, Ryan A, Pook D, Berman DM, Australian Prostate Cancer BioResource, Taylor RA \& Risbridger GP 2013 A preclinical xenograft model identifies castration-tolerant cancer-repopulating cells in localized prostate tumors. Science Translational Medicine 5 187ra171. (doi:10.1126/ scitranslmed.3005688)

Tomlinson DC, Grindley JC \& Thomson AA 2004 Regulation of Fgf10 gene expression in the prostate: identification of transforming growth factor- $\beta 1$ and promoter elements. Endocrinology 145 1988-1995. (doi:10.1210/en.2003-0842)

Uysal-Onganer P, Kawano Y, Caro M, Walker MM, Diez S, Darrington RS, Waxman J \& Kypta RM 2010 Wnt-11 promotes neuroendocrine-like differentiation, survival and migration of prostate cancer cells. Molecular Cancer 9 55. (doi:10.1186/1476-4598-9-55)

Van Wagenen G 1947 Maturity induced by testosterone in the young male monkey. Federation Proceedings 6219.

Wang Y, Sudilovsky D, Zhang B, Haughney PC, Rosen MA, Wu DS, Cunha TJ, Dahiya R, Cunha GR \& Hayward SW 2001 human prostatic epithelial model of hormonal carcinogenesis. Cancer Research 61 6064-6072.

Wasner G, Hennermann I \& Kratochwil K 1983 Ontogeny of mesenchymal androgen receptors in the embryonic mouse mammary gland. Endocrinology 113 1771-1780. (doi:10.1210/endo113-5-1771)

Weiss DA, Rodriguez E Jr, Cunha T, Menshenina J, Barcellos D, Chan LY, Risbridger G, Baskin L \& Cunha G 2012 Morphology of the external genitalia of the adult male and female mice as an endpoint of sex differentiation. Molecular and Cellular Endocrinology 354 94-102. (doi:10.1016/j.mce.2011.08.009)

Wikstrom P, Westin P, Stattin P, Damber JE \& Bergh A 1999 Early castration-induced upregulation of transforming growth factor $\beta 1$ and its receptors is associated with tumor cell apoptosis and a major decline in serum prostate-specific antigen in prostate cancer patients. Prostate 38 268-277. (doi:10.1002/(SICI) 1097-0045(19990301)38:4<268::AIDPROS2 > 3.0.CO;2-4)

Wikstrom P, Marusic J, Stattin P \& Bergh A 2009 Low stroma androgen receptor level in normal and tumor prostate tissue is related to poor outcome in prostate cancer patients. Prostate 69 799-809. (doi:10.1002/ pros.20927)

Wilkinson SE, Furic L, Buchanan G, Larsson O, Pedersen J, Frydenberg M, Risbridger GP \& Taylor RA 2013 Hedgehog signaling is active in human prostate cancer stroma and regulates proliferation and differentiation of adjacent epithelium. Prostate 73 1810-1823. (doi:10.1002/pros. 22720)

Wu JD, Haugk K, Woodke L, Nelson P, Coleman I \& Plymate SR 2006 Interaction of IGF signaling and the androgen receptor in prostate cancer progression. Journal of Cellular Biochemistry 99 392-401. (doi:10.1002/jcb.20929) 
Yan G, Fukabori Y, Nikolaropoulos S, Wang F \& McKeehan WL 1992 Heparin-binding keratinocyte growth factor is a candidate stromalto-epithelial-cell andromedin. Molecular Endocrinology 6 2123-2128. (doi:10.1210/mend.6.12.1491693)

Yang R, Ma YX, Chen LF, Zhou Y, Yang ZP, Zhu Y, Du XL, Shi JD, Ma HS \& Zhang J 2010 Antagonism of estrogen-mediated cell proliferation by raloxifene in prevention of ageing-related prostatic hyperplasia. Asian Journal of Andrology 12 735-743. (doi:10.1038/aja.2010.24)

Yeh S, Hu YC, Wang PH, Xie C, Xu Q, Tsai MY, Dong Z, Wang RS, Lee TH \& Chang C 2003 Abnormal mammary gland development and growth retardation in female mice and MCF7 breast cancer cells lacking androgen receptor. Journal of Experimental Medicine 198 1899-1908. (doi:10.1084/jem.20031233)
York TP, Plymate SR, Nelson PS, Eaves LJ, Webb HD \& Ware JL 2005 cDNA microarray analysis identifies genes induced in common by peptide growth factors and androgen in human prostate epithelial cells. Molecular Carcinogenesis 44 242-251. (doi:10.1002/mc. 20139)

Yu S, Yeh CR, Niu Y, Chang HC, Tsai YC, Moses HL, Shyr CR, Chang C \& Yeh S 2012 Altered prostate epithelial development in mice lacking the androgen receptor in stromal fibroblasts. Prostate 72 437-449. (doi:10.1002/pros.21445)

Yu S, Xia S, Yang D, Wang K, Yeh S, Gao Z \& Chang C 2013 Androgen receptor in human prostate cancer-associated fibroblasts promotes prostate cancer epithelial cell growth and invasion. Medical Oncology 30 674. (doi:10.1007/s12032-013-0674-9)

Received in final form 20 March 2014

Accepted 28 May 2014

Made available online as an Accepted Preprint

22 May 2014
Published by Bioscientifica Ltd. 